\title{
Implementation of Preference Selection Index Method in Decision Support System for Selecting School Inventory Users
}

\author{
Doris Yolanda Saragih ${ }^{1)}$, Kalvin Sinaga ${ }^{2)^{*}}$ \\ ${ }^{1) 2)}$ Politeknik Bisnis Indonesia, Indonesia \\ ${ }^{1)}$ dorisyolandasaragih@gmail.com, ${ }^{2}$ kal.sinaga@gmail.com
}

\begin{abstract}
This study aims to solve the problem of using a limited inventory of supporting media for learning at SD 096782 Tumorang Huta Dua Tumorang school, Gunung Maligas District, Simalungun Regency. The limitations of school inventories in the use of instructional media must be distributed to teachers so that they can be used in teaching. Therefore, the difficulty of distributing school inventory was overcome by implementing a decision support system using the Preference Selection Index (PSI) method. This method uses 6 criteria consisting of: years of service, behavior, performance, attendance, responsibility, and last education. The results of the application of the DSS with the PSI method obtained alternatives that are priority recommendations for school inventory users. The recommendation results obtained from the application of the DSS with the PSI method are Teacher 3 alternative with a final value of 0.8506 . The second alternative is Teacher 01 with a final score of 0.8190 and the third alternative is Teacher_07 with a final score of $0 . \overline{7} 846$.
\end{abstract}

Keywords: Inventory; DSS; PSI; Method; Teacher

\section{Introduction}

In the teaching and learning process, many obstacles are experienced during the activity, so that the learning objectives cannot be achieved optimally. For the learning objectives to be achieved properly, the teacher must overcome these obstacles. One way is by using learning media. Learning media is a tool that functions to help smooth the course of teaching and learning activities so that learning objectives are achieved properly. Each subject has varying levels of difficulty, there are learning materials that do not require tools, but there are learning materials that are very difficult so that they require tools because they have a high level of difficulty that is difficult for students to process and digest.

Learning media as a source of learning will help teachers enrich students' insights. The various forms and types of learning media used by teachers are a source of knowledge for students. Media as a learning resource is an auditive, visual, and audio-visual aid that is very useful in helping to facilitate students' understanding. In the past, in the teaching and learning process, the teacher was the only source of learning. Educational activities tend to be traditional. For example, in counting students still use pebbles, sticks, matches, so it is still difficult to count large numbers. Then with the rapid development of technology, calculating machines, namely calculators, began to be discovered. A calculator can calculate faster and less wrong.

In addition to calculating tools, other educational media have also experienced development, so that the media is not only a tool but a source of learning. In the teaching and learning process, some media only rely on voice skills (radio, cassettes, recorders, phonograph records), and media that rely on vision only (film strips/slides (frame films), photos, pictures, paintings, prints) which has sound elements and image elements (sound slides, video cassettes, sound film). Using the media in teaching and learning activities, especially at the elementary school level is very important. Because the presence of the media helps students understand a certain concept.

Teachers at SD 096782 Tumorang Huta Dua Tumorang Gunung Maligas District, Simalungun Regency are also expected to be able to use learning media as a tool in teaching students at the school. Currently, school inventory items as a tool that supports these learning media are very limited. Therefore, determining the use of school inventory items must be divided wisely so that each teacher can take turns using school inventory items in their use as a learning medium for students.

To assist the school in dividing the users of school inventory items as a learning medium, a decision support system was designed to determine the priority of the school inventory users. With this decision support system, the user of the inventory can be done well. 


\section{Literatur Review}

The use of technology in its development plays a very important role in life (Mulia Siregar \& Sugara, 2018; Purba $\&$ Siregar, 2020; S et al., 2020; Siregar, 2018; Tamba, Batubara, et al., 2019). The need for information that is used as the basis for decision-making in every organization is also increasingly needed. Therefore, decision-making nowadays involves more and more use of computer technology (Aisyah \& Purba, 2019; Purba, 2018; Sahat Sonang, 2018; Simatupang, 2018; Tamba, Wulandari, et al., 2019), (Salim, 2018).

A good and structured decision-making system will produce a system that can support teacher performance in teaching at SD 096782 Tumorang Huta Dua Tumorang school, Gunung Maligas District, Simalungun Regency. The decision-making system for determining the priority of using school inventory as a learning medium in this school was built using the Preference Selection Index (PSI) method. This method is used because it can provide a good solution in the choice of decisions (Attri \& Grover, 2015; Jian \& Ying, 2017; Puspitasari et al., 2020).

\section{Method}

The stages carried out in this study can be seen in Figure 1. The stages of the research were started by collecting data on teachers at SD 096782 Tumorang Huta Dua Tumorang, Gunung Maligas District, Simalungun Regency. Furthermore, determining the criteria for inventory users and determining the weight for each criterion. The next step is to process the data that has been collected to obtain a list of recommendations for teachers who use school inventories.

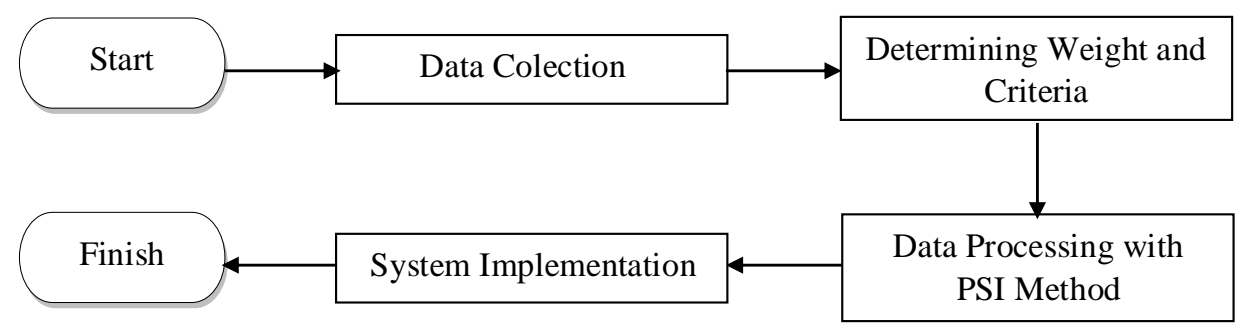

Fig. 1 Research Framework

The data processing stages were carried out using the PSI method starting from formulating the decision matrix, followed by the decision matrix normalization. Next, calculate the mean value of the normalized data and continue by calculating the value of the preference variation. Next, determine the deviation in preference values and then determine the weights. Then the index preference selection for each alternative is carried out so that an appropriate alternative is obtained for the school inventory users (Panggabean \& Hasibuan, 2020; Siahaan et al., 2018).

The criteria used in the Implementation of the preference selection index method in the decision support system for selecting school inventory users consist of the criteria listed in table 1.

Table 1

Criteria Used

\begin{tabular}{lll}
\hline \hline Criteria & Information & Type \\
\hline C1 & Years Of Service & Benefit \\
C2 & Behavior & Benefit \\
C3 & Performance & Benefit \\
C4 & Attendance & Benefit \\
C5 & Responsibility & Benefit \\
C6 & Last Education & Benefit \\
\hline
\end{tabular}

Alternative data along with the criteria values for each alternative to be processed in this study can be seen in table 2. The data in table 2 consists of data from 8 prospective teachers who use school inventory to be processed using the Preference Selection Index (PSI) method along with the criteria for each teacher.

Table 2

Alternative Data and Value Criteria for Each Alternative

\begin{tabular}{ccccccc}
\hline \hline \multirow{2}{*}{ Alternatives } & \multicolumn{5}{c}{ Value Criteria for Each Alternative } \\
\cline { 2 - 7 } & $\mathrm{C} 1$ & $\mathrm{C} 2$ & $\mathrm{C} 3$ & $\mathrm{C} 4$ & $\mathrm{C} 5$ & $\mathrm{C} 6$ \\
\hline
\end{tabular}


Journal of Computer Networks, Architecture and High Performance Computing

e-ISSN 2655-9102, Volume 2, No. 2, Juni 2020, pp 327 -332

\begin{tabular}{lllllll}
\hline Teacher_01 & 5 & 2 & 4 & 20 & 3 & 5 \\
Teacher_02 & 5 & 2 & 2 & 65 & 2 & 5 \\
Teacher_03 & 5 & 3 & 3 & 35 & 3 & 5 \\
Teacher_04 & 4 & 1 & 2 & 85 & 1 & 2 \\
Teacher_05 & 1 & 2 & 2 & 85 & 2 & 2 \\
Teacher_06 & 1 & 1 & 2 & 100 & 2 & 3 \\
Teacher_07 & 1 & 2 & 3 & 100 & 2 & 5 \\
\hline
\end{tabular}

\section{4. .Result}

To get the results of recommendations from users of school inventory as a learning medium at SD 096782 Tumorang Huta Dua Tumorang Gunung Maligas District, Simalungun Regency, it was carried out using the Preference Selection Index (PSI) method which consists of:

Formulate a decision matrix such as the following matrix N.

$$
N=\left[\begin{array}{cccccc}
5 & 2 & 4 & 20 & 3 & 5 \\
5 & 2 & 2 & 65 & 2 & 5 \\
5 & 3 & 3 & 35 & 3 & 5 \\
4 & 1 & 2 & 85 & 1 & 2 \\
1 & 2 & 2 & 85 & 2 & 2 \\
1 & 1 & 2 & 100 & 2 & 3 \\
1 & 2 & 3 & 100 & 2 & 5
\end{array}\right]
$$

Based on the above matrix, normalization is carried out to obtain the following matrix.

$$
N_{i j}=\left[\begin{array}{cccccc}
1 & 0,6667 & 1 & 0,2 & 1 & 1 \\
1 & 0,6667 & 0,5 & 0,65 & 0,6667 & 1 \\
1 & 1 & 0,75 & 0,35 & 1 & 1 \\
0,8 & 0,3333 & 0,5 & 0,85 & 0,3333 & 0,4 \\
0,2 & 0,6667 & 0,5 & 0,85 & 0,6667 & 0,4 \\
0,2 & 0,3333 & 0,5 & 1 & 0,6667 & 0,6 \\
0,2 & 0,6667 & 0,75 & 1 & 0,6667 & 1
\end{array}\right]
$$

The sum of each attribute in the matrix above, namely:

$\sum_{1}^{n}=1 N_{i j}=\left[\begin{array}{llllll}4,4 & 4,3333 & 4,5 & 4,9 & 5 & 5,4\end{array}\right]$

Next, calculate the mean value of the results that have been obtained from the matrix above.

$N_{j 1}=\frac{1}{7} \times 4,4=0,6286$

$N_{j 2}=\frac{1}{7} \times 4,3333=0,6190$

$N_{j 3}=\frac{1}{7} \times 4,5=0,6429$

$N_{j 4}=\frac{1}{7} \times 4,9=0,7$

$N_{j 5}=\frac{1}{7} \times 5=0,7143$

$N_{j 6}=\frac{1}{7} \times 5,4=0,7714$

The results of the above calculations get the mean value consisting of :

$N=\left[\begin{array}{llllll}0,6286 & 0,6190 & 0,6429 & 0,7 & 0,7143 & 0,7714\end{array}\right]$

Furthermore, the calculation of the value of the Preference variation is carried out
$\emptyset_{j 1}$
$\emptyset_{j 4}$ 


$$
\begin{array}{ll}
\emptyset_{j 11}=\sum_{i}^{n}(1-0,6286)^{2}=0,1380 & \emptyset_{j 14}=\sum_{i}^{n}(0,2-0,7)^{2}=0,2500 \\
\emptyset_{j 21}=\sum_{i}^{n}(1-0,6286)^{2}=0,1380 & \emptyset_{j 24}=\sum_{i}^{n}(0,65-0,7)^{2}=0,0025 \\
\emptyset_{j 31}=\sum_{i}^{n}(1-0,6286)^{2}=0,1380 & \emptyset_{j 34}=\sum_{i}^{n}(0,35-0,7)^{2}=0,1225 \\
\emptyset_{j 41}=\sum_{i}^{n}(0,8-0,6286)^{2}=0,0294 & \emptyset_{j 44}=\sum_{i}^{n}(0,85-0,7)^{2}=0,0225 \\
\emptyset_{j 51}=\sum_{i}^{n}(0,2-0,6286)^{2}=0,1837 & \emptyset_{j 54}=\sum_{i}^{n}(0,85-0,7)^{2}=0,0225 \\
\emptyset_{j 61}=\sum_{i}^{n}(0,2-0,6286)^{2}=0,1837 & \emptyset_{j 64}=\sum_{i}^{n}(1-0,7)^{2}=0,0900 \\
\emptyset_{j 71}=\sum_{i}^{n}(0,2-0,6286)^{2}=0,1837 & \emptyset_{j 74}=\sum_{i}^{n}(1-0,7)^{2}=0,0900 \\
\emptyset_{j 2} & \\
\emptyset_{j 12}=\sum_{i}^{n}(0,6667-0,6190)^{2}=0,0023 & \emptyset_{j 5} \\
\emptyset_{j 22}=\sum_{i}^{n}(0,6667-0,6190)^{2}=0,0023 & \emptyset_{j 15}=\sum_{i}^{n}(1-0,7143)^{2}=0,0816 \\
\emptyset_{j 32}=\sum_{i}^{n}(1-0,6190)^{2}=0,1451 & \emptyset_{j 25}=\sum_{i}^{n}(0,6667-0,7143)^{2}=0,0023 \\
\emptyset_{j 42}=\sum_{i}^{n}(0,3333-0,6190)^{2}=0,0816 & \emptyset_{j 35}=\sum_{i}^{n}(1-0,7143)^{2}=0,0816 \\
\emptyset_{j 52}=\sum_{i}^{n}(0,6667-0,6190)^{2}=0,0023 & \emptyset_{j 45}=\sum_{i}^{n}(0,3333-0,7143)^{2}=0,1451 \\
\emptyset_{j 62}=\sum_{i}^{n}(0,3333-0,6190)^{2}=0,0816 & \emptyset_{j 55}=\sum_{i}^{n}(0,6667-0,7143)^{2}=0,0023 \\
\emptyset_{j 72}=\sum_{i}^{n}(0,6667-0,6190)^{2}=0,0023 & \emptyset_{j 65}=\sum_{i}^{n}(0,6667-0,7143)^{2}=0,0023 \\
& \emptyset_{j 75}=\sum_{i}^{n}(0,6667-0,7143)^{2}=0,0023 \\
\emptyset_{j 3} & \\
\emptyset_{j 13}=\sum_{i}^{n}(1-0,6429)^{2}=0,1276 & \emptyset_{j 6} \\
\emptyset_{j 23}=\sum_{i}^{n}(0,5-0,6429)^{2}=0,0204 & \emptyset_{j 16}=\sum_{i}^{n}(1-0,7714)^{2}=0,0522 \\
\emptyset_{j 33}=\sum_{i}^{n}(0,75-0,6429)^{2}=0,0115 & \emptyset_{j 26}=\sum_{i}^{n}(1-0,7714)^{2}=0,0522 \\
\emptyset_{j 43}=\sum_{i}^{n}(0,5-0,6429)^{2}=0,0204 & \emptyset_{j 36}=\sum_{i}^{n}(1-0,7714)^{2}=0,0522 \\
\emptyset_{j 53}=\sum_{i}^{n}(0,5-0,6429)^{2}=0,0204 & \emptyset_{j 46}=\sum_{i}^{n}(0,4-0,7714)^{2}=0,1380 \\
\emptyset_{j 63}=\sum_{i}^{n}(0,5-0,6429)^{2}=0,0204 & \emptyset_{j 56}=\sum_{i}^{n}(0,4-0,7714)^{2}=0,1380 \\
\emptyset_{j 73}=\sum_{i}^{n}(0,75-0,6429)^{2}=0,0115 & \emptyset_{j 66}=\sum_{i}^{n}(0,6-0,7714)^{2}=0,0294 \\
& \emptyset_{j 76}=\sum_{i}^{n}(1-0,7714)^{2}=0,0522
\end{array}
$$

Furthermore, the calculation of the value of the Preference variation is carried out and the results obtained are the following matrix.

$$
\emptyset_{j}=\left[\begin{array}{llllll}
0,1380 & 0,0023 & 0,1276 & 0,2500 & 0,0816 & 0,0522 \\
0,1380 & 0,0023 & 0,0204 & 0,0025 & 0,0023 & 0,0522 \\
0,1380 & 0,1451 & 0,0115 & 0,1225 & 0,0816 & 0,0522 \\
0,0294 & 0,0816 & 0,0204 & 0,0225 & 0,1451 & 0,1380 \\
0,1837 & 0,0023 & 0,0204 & 0,0225 & 0,0023 & 0,1380 \\
0,1837 & 0,0816 & 0,0204 & 0,0900 & 0,0023 & 0,0294 \\
0,1837 & 0,0023 & 0,0115 & 0,0900 & 0,0023 & 0,0522
\end{array}\right]
$$

The sum of the matrices above is as follows :

$$
\emptyset_{j}=\left[\begin{array}{llllll}
0,9943 & 0,3175 & 0,2321 & 0,6 & 0,3175 & 0,5143
\end{array}\right]
$$

Determines the deviation in the preference value.

$$
\begin{aligned}
& \Omega_{1}=1-0,9943=0,01 \\
& \Omega_{2}=1-0,3175=0,68 \\
& \Omega_{3}=1-0,2321=0,77 \\
& \Omega_{4}=1-0,6=0,4 \\
& \Omega_{5}=1-0,3175=0,68 \\
& \Omega_{6}=1-0,5143=0,49
\end{aligned}
$$

The calculation result of the preference value produces the $\Omega \mathrm{j}$ matrix.

$$
\Omega_{j}=\left[\begin{array}{llllll}
0,01 & 0,68 & 0,77 & 0,40 & 0,68 & 0,49
\end{array}\right]
$$


The total value of the overall matrix $\Omega \_j$

$\Sigma \Omega_{j}=0,01+0,68+0,77+0,40+0,68+0,49=3,02$

Determining Weight Criteria.

$$
\begin{aligned}
& W_{j}=\frac{n_{j}}{\sum_{1=1}^{n} \Omega_{j}}=\frac{0,01}{3,02}=0.0019 \\
& W_{j}=\frac{n_{j}}{\sum_{1=1}^{n} \Omega_{j}}=\frac{0,68}{3,02}=0.2257 \\
& W_{j}=\frac{n_{j}}{\sum_{1=1}^{n} \Omega_{j}}=\frac{0,77}{3,02}=0.2539 \\
& W_{j}=\frac{n_{j}}{\sum_{1=1}^{n} \Omega_{j}}=\frac{0,4}{3,02}=0.1323 \\
& W_{j}=\frac{n_{j}}{\sum_{1=1}^{n} \Omega_{j}}=\frac{0,68}{3,02}=0.2257 \\
& W_{j}=\frac{n_{j}}{\sum_{1=1}^{n} \Omega_{j}}=\frac{0,49}{3,02}=0.1606 \\
& W_{j}=\left[\begin{array}{llllll}
0.0019 & 0.2257 & 0.2539 & 0.1323 & 0.2257 & 0.1606
\end{array}\right]
\end{aligned}
$$

Next, calculate the PSI and get the results like the matrix below.

$$
\text { Matrix } \theta_{i j}=\left[\begin{array}{cccccc}
0.0019 & 0.1505 & 0.2539 & 0.0265 & 0.2257 & 0.1606 \\
0.0019 & 0.1505 & 0.1269 & 0.0860 & 0.1505 & 0.1606 \\
0.0019 & 0.2257 & 0.1904 & 0.0463 & 0.2257 & 0.1606 \\
0.0015 & 0.0752 & 0.1269 & 0.1124 & 0.0752 & 0.0642 \\
0.0004 & 0.1505 & 0.1269 & 0.1124 & 0.1505 & 0.0642 \\
0.0004 & 0.0752 & 0.1269 & 0.1323 & 0.1505 & 0.0964 \\
0.0004 & 0.1505 & 0.1904 & 0.1323 & 0.1505 & 0.1606
\end{array}\right]
$$

Finding Ranking Values

$$
\begin{aligned}
& \theta_{1}=(-0,001592)+(-0,000318)+(-0,003691)+3,409280+(-0,002842)+(-0,003307)=3,395953 \\
& \theta_{2}=(-0,001592)+(-0,001895)+(-0,001846)+11,080161+(-0,001895)+(-0,003307)=11,069626 \\
& \theta_{3}=(-0,001592)+(-0,002842)+(-0,002768)+5,966240+(-0,002842)+(-0,003307)=5,952888 \\
& \theta_{4}=(-0,001274)+(-0,000947)+(-0,001846)+14,489441+(-0,000947)+(-0,001323)=14,483104 \\
& \theta_{5}=(-0,000318)+(-0,001895)+(-0,001846)+14,489441+(-0,001895)+(-0,001323)=14,482165 \\
& \theta_{6}=(-0,00318)+(-0,000947)+(-0,001846)+17,046401+(-0,001895)+(-0,001984)=17,039411 \\
& \theta_{7}=(-0,00318)+(-0,001895)+(-0,002768)+17,046401+(-0,001895)+(-0,003307)=17,036218
\end{aligned}
$$

The ranking results for the priority of school inventory users can be seen in Figure 2. 


\section{Ranking Result Graph}

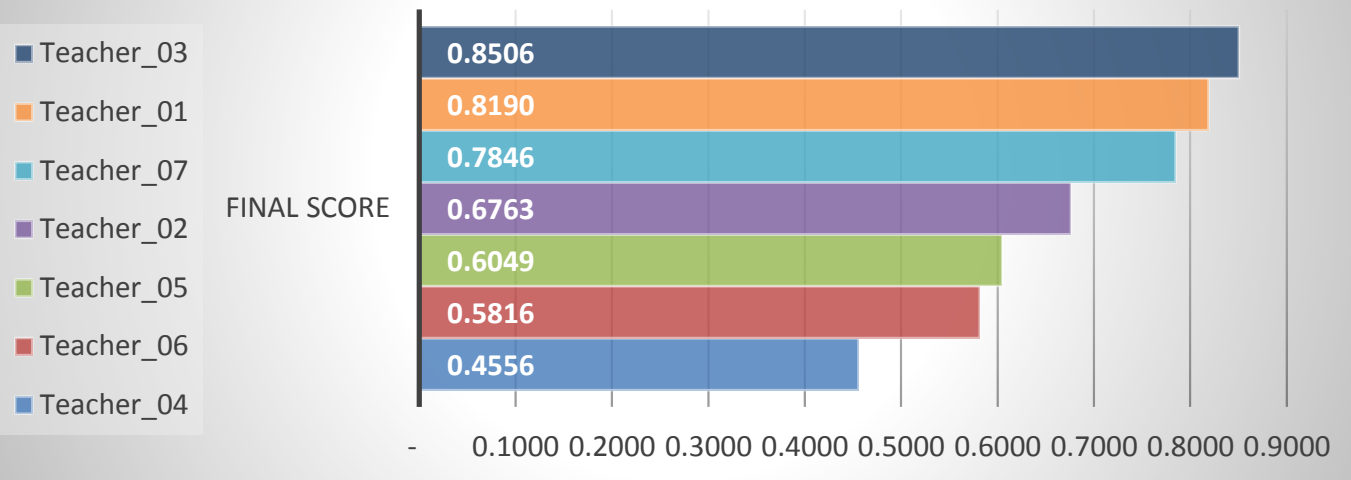

Fig. 2 Ranking Result Graph

\section{Discussion}

Based on the results of the ranking in Figure 2, it can be seen that the 3 teachers who got the highest order or priority to be able to first use school inventory in supporting the use of instructional media were the Teacher_3 alternative with a final score of 0.8506 . The second alternative is Teacher_01 with a final score of 0.8190 and the third alternative is the Teacher_07 alternative with a final score of 0.7846 .

\section{Conclusion}

Based on the implementation of the preference selection index method in the decision support system for selecting school inventory users, determining the priority of teachers using school inventory can be easily done. The criteria used in this decision support system consist of 6 criteria consisting of tenure, behavior, performance, attendance, responsibility, and last education. The results of the application of this decision support system can help the school at SD Negeri 096782 Tumorang Huta Dua Tumorang Gunung Maligas District, Simalungun Regency in determining teacher priorities in the use of school inventory.

\section{REFERENCES}

Aisyah, S., \& Purba, W. (2019). Aplikasi Sistem Pendukung Keputusan Penilaian Kinerja Karyawan Menggunakan Metode Profile Matching. Jurnal Mahajana Informasi, 4(2), 16-20.

Attri, R., \& Grover, S. (2015). Application of preference selection index method for decision making over the design stage of production system life cycle. Journal of King Saud University - Engineering Sciences, 27(2), 207-216. https://doi.org/10.1016/j.jksues.2013.06.003

Jian, S., \& Ying, S. (2017). Preference selection index method for machine selection in a flexible manufacturing cell. MATEC Web of Conferences, 139, 4-7. https://doi.org/10.1051/matecconf/201713900167

Mulia Siregar, V. M., \& Sugara, H. (2018). Implementation of artificial neural network to assesment the lecturer's performance. IOP Conference Series: Materials Science and Engineering, 420(1), 012112. https://doi.org/10.1088/1757-899X/420/1/012112

Panggabean, R., \& Hasibuan, N. A. (2020). Penerapan Preference Selection Index (PSI) Dalam Sistem Pendukung Keputusan Pengangkatan Supervisor Housekeeping. Rekayasa Teknik Informatika Dan Informasi, 1(2), 85-93.

Purba, A. T. (2018). Sistem Pendukung Keputusan Dalam Penerimaan Mahasiswa Baru Dengan Metode Analytical Hierarchy Process (AHP). Jurnal Tekinkom, 1(1), 1-7.

Purba, A. T., \& Siregar, V. M. M. (2020). Sistem Penyeleksi Mahasiswa Baru Berbasis Web Menggunakan Metode Weighted Product. Jurnal Teknik Informasi Dan Komputer (Tekinkom), 3(1), 1. https://doi.org/10.37600/tekinkom.v3i1.117

Puspitasari, D., Wijaya, I. D., \& Mentari, M. (2020). Decision support system for determining the activities of the study program using the Preference Selection Index. IOP Conference Series: Materials Science and Engineering, 732(1), 012073. https://doi.org/10.1088/1757-899X/732/1/012073

S, S. S., Purba, A. T., \& Siregar, V. M. M. (2020). Sistem Pendukung Keputusan Kelayakan Pemberian Pinjaman Kredit Menggunakan Metode Topsis Pada Cum Caritas HHKBP Pematangsiantar. Jurnal Teknik Informasi Dan 
Komputer (Tekinkom), 3(1), 1. https://doi.org/10.37600/tekinkom.v3i1.117

Sahat Sonang. (2018). Implementasi K-Means Dalam Evaluasi Kinerja Dosen Politeknik Bisnis Indonesia. Jurnal Tekinkom, 1(1), 32-40. https://doi.org/10.1017/CBO9781107415324.004

Salim, M. A. (2018). Sistem Pendukung Keputusan Pemilihan Penerima Bantuan Perbaikan Rumah Menggunakan Metode Simple Additive Wieghting (SAW) Studi Kasus Kelurahan Tambelan Sampit Kota Pontianak. Jurnal SISTEMASI, 7(2), 120-131. https://doi.org/DOI : https://doi.org/10.32520/stmsi.v7i2.293.g124

Siahaan, M. K., Mesran, M., Hutabarat, S. A., \& Afriany, J. (2018). SISTEM PENDUKUNG KEPUTUSAN PENENTUAN PRIORITAS PEMBANGUNAN DAERAH MENERAPKAN METODE PREFERENCE SELECTION INDEX (PSI). KOMIK (Konferensi Nasional Teknologi Informasi Dan Komputer), 2(1), 370-375. https://doi.org/10.30865/komik.v2i1.961

Simatupang, J. (2018). Sistem Pendukung Keputusan Penentuan Karyawan Terbaik Menggunakan Metode Saw Studi Kasus Amik Mahaputra Riau. Jurnal Intra-Tech, 2(1), 73-82.

Siregar, V. M. M. (2018). Sistem Pendukung Keputusan Penentuan Insentif Bulanan Pegawai Dengan Menggunakan Metode Naïve Bayes. SISTEMASI, 7(2), 87-94.

Tamba, S. P., Batubara, M. D., Purba, W., Sihombing, M., Mulia Siregar, V. M., \& Banjarnahor, J. (2019). Book data grouping in libraries using the k-means clustering method. Journal of Physics: Conference Series, 1230(1), 012074. https://doi.org/10.1088/1742-6596/1230/1/012074

Tamba, S. P., Wulandari, P., Hutabarat, M., Christina, M., \& Oktavia, A. (2019). PENGGUNAAN METODE TOPSIS (TECHNIQUE FOR ORDER PREFERENCE BY SIMILARITY TO IDEAL SOLUTION) UNTUK MENENTUKAN KUALITAS BIJI KOPI TERBAIK BERBASIS ANDROID. Jurnal Mantik Penusa, 3(1), 7381. 